\title{
МЕЖДУНАРОДНЫЕ КОНФЛИКТЫ
}

Филиппов B.P.

DOI: $10.7256 / 2305-560 X .2016 .1 .16829$

\section{ЧАД: ВОЙНА ВСЕХ ПРОТИВ ВСЕХ}

Аннотация. Используя метод исторической реконструкции, автор показывает латентные причины и неоколониальный характер гражданской войны в Республике Чад - одного из самых продолжительных и кровавых конфликтов на африканском континенте в постколониальный период. Комплексный анализ малоизвестных исторических источников (материалов судебных и журналистских расследований, свидетельств известных политиков и дипломатов) позволяет выяснить побудительные мотивы и цели самых разных акторов политического процесса в этом внутригосударственном и международном противостоянии, а также оценить перспективы разрешения конфликта в будущем. Методологической основой исследования является системный, структурно-функциональный, сравнительно-политический подходы, методы анализа, синтеза, индукции, дедукции, наблюдения. Акцент сделан на выяснении роли Франции в развязывании гражданской войны в Чаде, а также ее политики (политики «Франсафрик») в отношении других стран, втянутых в военные действия - США, Ливии, Судана. Показана тесная связь между событиями в Республике Чад и войной в Дарфуре. Обоснован вывод о том, что Пятая республика инспирировала и долгое время поддерживала межконфессиональное и межрасовое противостояние с целью сохранения экономических и политических префреренций Парижа в этом богатом ураном и стратегически важном регионе. Исследование выполнено при финансовой поддержке РГНФ, проект № 15-01-00363, «Внешнее вмешательство во внутренние дела стран «третьего мира» в эпоху “холодной войны»: опыт многоуровневого анализа»

Ключевые слова: геополитика, индекс восприятия коррупции, мировая политика, глобальная нестабильность, социально-политические процессы, дипломатия, интересы, государство, безопасность, риски.

Abstract. Using the method of historical reconstruction, the author shows the latent causes and the neo-colonial character of the civil war in the Republic of Chad - one of the longest and the bloodiest conflicts in Africa in the postcolonial period. Comprehensive analysis of the little-known historical sources (materials of judicial and investigative journalism, evidences of well-known politicians and diplomats) allows finding out the motives and goals of many different actors of the political process in the domestic and international conflict, and estimating the perspectives of future conflict resolution. The research methodology comprises the system, structural-functional, and comparative political approaches, the methods of analysis, synthesis, induction, and observation. The author focuses on clarifying the role of France in the civil war in Chad outbreak, and on its policy (the "Françafrique» policy) towards other countries involved in military operations - the United States, Libya, Sudan. The author demonstrates the close connection between the events in the Republic of Chad and the war in Darfur. The study substantiates the statement that the Fifth Republic has inspired and has been supporting for a long time interconfessional and interracis/ confrontation in order to maintain the economic and political preferences of Paris in this uranium-rich and strategically important region. The study was funded by RHF project number 15-01-00363, "External interference in the internal affairs of the countries of the» third world "in an era of the "Cold War ": the experience of multilevel analysis».

Key words: geopolitics, corruption perception index, world policy, global instability, socio-political processes, diplomacy, interests, state, security, risks.

$\mathrm{H}$ оминально Республика Чад обрела государственный суверенитет 11 августа 1960 года. Но, будучи вынуждена предоставить независимость своим колониям, Франция сделала все, чтобы сохранить свое политическое, экономическое и военное влияние на Черном континенте. В соответствии с провозглашенным генералом Шарлем де Голлем принципом «Уйти так, чтобы остаться», Елисейский дворец стремился оставить в своих бывших колониях правителей, целиком зависимых от бывшей метрополии и полностью ей подконтрольных. Это в разной мере удалось осуществить почти во всех молодых квази-государ-

ствах, образовавшихся на развалинах французской колониальной империи в Западной тропической Африке. В полной мере это относится к Чад. Президентом и премьер-министром Чада стал Франсуа Томбалбай, сделавший быструю административную, а затем и политическую карьеру еще в годы французского владычества.

\section{Чад пути к независимости}

В 1942 г. Ф. Томбалбай лишь скромный учитель одной из школ Форт-Лами (тепрь Нджамена, столица Республики Чад). Впервые заявил о себе как 
профсоюзный активист. В 1946 г., когда Франция нехотя приступила к реформированию политической системы распадающейся империи, он был избран (фактически назначен) территориальным советником - членом Территориальной ассамблеи французской Заморской территории Чад. В 19461947 гг. он принимает самое деятельное участие в создании чадской секции Африканского Демократического объединения - АДО (Rassemblement Democratique Africain - RDA), которая стала самостоятельной политической структурой, получившей название Прогрессивной партии Чада - ППч (Parti progressiste Tchadien - РРT). Основателем ППЧ и в то время ее признанным лидером был француз, выходец из Панамы, сотрудник французской администрации Габриэль Лизетт. Первоначально эта левацкая радикально-националистическая партия не вызывала симпатии колониальных властей, а тем более - чадской родоплеменной элиты. Однако позже было решено использовать ее популярность для достижения латентных целей метрополии. Политические манипуляции позволили поставить ППЧ под контроль племенных вождей и сделать ее рупором интересов наиболее продвинутых слоев христианского населения южных территорий [1]. Будучи одним из лидеров этой политической структуры Ф. Томбалбай в 1951 г. вошел в Большой совет Французской экваториальной Африки. Одновременно он фактически создал, а затем и возглавил Союз автономных профсоюзов Чада. В 1952-1959 гг., не оставляя профсоюзную и политическую деятельность, он стал управляющим Кредитного общества Экваториальной Африки, главой службы почты и телеграфа, управляющим общества радиовещания Французских заморских территорий. Наконец, в 1957 г. Елисейский дворец доверил ему пост вице-президента Правительственного совета Французской Экваториальной Африки, а в марте 1959 г. он стал главой кабинета Автономной Республики Чад в составе Французского сообщества [2].

31 мая 1959 г. состоялись выборы депутатов Законодательного собрания, на которых ППЧ получила 57 из 85 депутатских мандатов. Ф. Томбалбай стал легитимным главой правительства Автономной Республики Чад, однако его власть эфемерна и ограничена компетенциями метрополии. Экономика автономии была убыточной, республика жила за счет дотаций из французского бюджета. Единственным богатством страны был хлопок; он давал три четверти экспортных доходов, но хлопок-сырец по монопольно низким ценам скупался и экспортировался французской компанией «Котонфран». Нет нужды говорить о том, что власть главы автономии в таких условиях могла быть лишь номинальной.
Но не экономические проблемы, не нищета были камнем преткновения главы кабинета автономии. Еще до получения формального суверенитета в стране обнаружилось политическое противостояние, которое вскоре стало причиной драматичного и кровавого противостояния граждан Республики Чад. Достаточно взглянуть на карту Африки, чтобы понять, что границы страны были определены крайне произвольно и были результатом торга между Францией, Великобританией и Италией. Они были прочерчены без учета социолингвистического, культурного, конфессионального своеобразия населения страны, без учета особенностей культуры жизнеобеспечения населения территорий. Север страны, провинции Борку, Эннеди и Тибести - это пески Сахары и Сахеля, в которых испокон веков кочевали арабы и племена социолингвистической общности тубу, исповедовавшие ислам. На юге, в саванне, жили темнокожие племена, преимущественно сара, занимавшиеся земледелием и исповедовавшие христианство. Историческая память темнокожих чадцев отягощена преданиями о том, как кочевники-арабы захватывали в плен и продавали в рабство их пращуров. По понятным причинам особой симпатии друг к другу представители этих общин не испытывали. Французы во времена своего владычества в Африке делали ставку не на строптивых кочевников, а на более покладистых оседлых африканцев. Это и понятно: франкоговорящие христиане легко обучались в католических школах и использовались в колониальных структурах власти «на земле». Да и с точки зрения экономической привлекательности хлопкопрозводящие южные районы были куда интереснее, чем пески Сахары и Сахеля.

После образования Автономной Республики Чад, в администрации этого квази-государственного образования безусловно доминировали южане, интересы которых выражал Ф. Томбалбай и созданная им ППЧ. Северяне же создали пять первоначально независимых политических структур, самой значительной из которых стало Африканское националистическое движение. Позже, 1 февраля 1960 г. мусульмане севера консолидировались и создали Африканскую национальную партию AНП (Parti national africain - PNA), которую возглавил министр юстиции в правительстве автономии Дауд Кераллах. Идеологи этой партии, предвидя грядущие столкновения с южанами, выступили против предоставления Чаду независимости до формального размежевания мусульманского Севера и христианского Юга под эгидой Франции. Целью северян было образование на территории региона Борку-Энди-Тибести независимого исламского государства. Партия активно выступала за 
ограничение активности иностранного, прежде всего - французского, капитала в стране.

Ф. Томбалбай, напротив, рассчитывал воспользоваться покровительством Франции и распространить свою власть на всю территорию суверенной Республики Чад. В феврале 1960 г. он отправился в Банги на конференцию глав автономий, входивших в состав Французской экваториальной Африки, и в числе прочих политических лидеров обратился к президенту Ш. де Голлю с прошением о предоставлении полной независимости бывшим колониям Франции. В апреле и Законодательное собрание чадской автономии призывало Францию предоставить республике государственный суверенитет.

В июле того же года Ф. Томбалбай отправился на переговоры в Париж. В результате этих переговоров 12 июля Республика Чад вместе с ЦАР и Конго подписала с Францией соглашение о предоставлении независимости. Через две недели было подписано соглашение о присоединении Республики к Французскому Сообществу.

\section{Диктатура Ф. Томбалбая и раскол страны}

11 августа 1960 г. Республика Чад стала независимым государством, президентом страны был провозглашен Ф. Томбалбай. При этом суверенитет получили только южные провинции Республики, северные же управлялись Францией до 1965 г., вплоть до того момента когда Елисейский дворец решил, что центральное правительство Чада достаточно компетентно и влиятельно, чтобы взять управление севером страны на себя. (Иначе говоря, лишь в 1965 г. генерал де Голль счел за благо передать Ф. Томбалбаю полномочия представлять интересы бывшей метрополии на всей территории Чад.)

Преисполненный благодарности Ф. Томбалбай 11 января 1961 г. засвидетельствовал верноподданнические чувства бывшей метрополии: «Наша цель - дружба и сотрудничество с Францией» [3]. Незамедлительно были заключены соглашения с Елисейским дворцом в области экономики и обороны, которые фактически легитимировали контроль сетей «Франсафрик» дворца над формально независимым государством. Социальной базой режима, как и в других бывших колониях Франции, стали родоплеменные вожди юга страны и бюрократия, сформировавшаяся при французском владычестве.

Политическим инструментом обеспечения личной власти Ф. Томбалбай сделал ППЧ. После того, как Франция якобы даровала независимость Республике Чад, Ф. Томбалбай сместил Г. Лизетта с поста председателя партии и на декабрьском съезде 1960 г. стал ее председателем.
В марте 1962 г. на парламентских выборах ППЧ одержала сокрушительную победу (она получила $80 \%$ голосов избирателей). В стране была установлена однопартийная система, все оппозиционные партии были запрещены. Однопартийная система была одобрена в 1963 г. на пятом съезде партии [4]. В июне 1964 г. Национальное собрание предоставило Ф. Томбалбаю эксклюзивное право формирования Политбюро ППЧ, что в условиях однопартийной системы означало переход к диктатуре этого одиозного лидера. Нужно иметь в виду, что практически все взрослое население страны - более 2 млн. чел. - состояло в рядах правящей партии [5]. В том же году Ф. Томбалбай инициировал создание военизированной молодежной организации «Движение чадской молодежи», призванное стоять на защите режима его личной власти. В 1969 г. диктатор издал декрет, согласно которому были расширены права традиционных вождей: родо-племенная «аристократия» рассматривалась как «вспомогательный аппарат администрации». Позже, в 1972 г. в Чад были реанимированы султанаты. Все это абсолютно устраивало Елисейский дворец, так как гарантировало защиту французских интересов в бывшей колонии.

Однако ощутимую угрозу для Франции представляли северные территории страны, население которых стремилось к созданию собственного государства, к реальной независимости от бывшей метрополии и от южного правительства Республики Чад. Еще во времена колониальных захватов наиболее жесткое сопротивление французам оказывали мусульмане северных районов страны. Традиционные институты власти и исламские ценности арабского населения оказались здесь очень устойчивым, кочевники отторгали все ассимиляторские устремления французской администрации. Ф. Томбалбай, искавший поддержки у южан (во властные и силовые структуры рекрутировались, как правило, представители социолингвистической общности сара, к которой принадлежал сам президент), очевидно дискриминировал население северных провинций. Кроме того, хлопок, приносивший пусть небольшие, но устойчивые экспортные доходы, культивировался на юге и по этой объективной причине доходы южан были заметно выше, нежели у северян. На фоне экономических неудач правительства религиозные и региональные разногласия приобретали все более антагонистический характер.

В 1962 г. кочевое племя балла восстало против попыток запретить традиционное исламское образование на территории своих кочевий. 1 ноября 1965 г. началось массовое вооруженное восстание арабских племен в префектуре Гера. Бунт был спровоцирован принудительным взыманием 
с кочевников «национальной ссуды». В ходе восстания погибли около пятисот человек. Но правительственные войска были слишком слабы, для того, чтобы успокоить северные провинции. Ф. Томбалбай обратился за помощью к Франции. Елисейский дворец направил на север Чада иностранный легион, но потребовал провести административную реформу в стране. В 1966 г. из Гера и соседней префектуры Батна восстание распространилось в Оуадда и Саламат [6]. Правительственные войска при поддержке французских легионеров жестоко карали бунтовавших кочевников, часть из которых была вынуждена покинуть территорию Чада.

Участие французских военных в боевых действиях вызвало негативную реакцию в африканских странах. Кроме того, они слишком дорого стоили французским налогоплательщикам. В 1966 г. было принято решение о выводе французских военных из северных провинций Чада, французское участие в конфликте в этот период ограничивалось логистической поддержкой и обеспечением воздушного прикрытия операций правительственных войск. На театре военных действий работали четыре штурмовика A-1H Skyraider, транспортные самолеты и вертолеты [7].

\section{Создание Фронта национального освобождение Чада}

В 1966 г. в городе Ньяла в Судане несколько разрозненных эмигрантских политических структур объединились и создали Фронт национального освобождение Чада - ФРОЛИНА (Front de Libération Nationale du Tchad - FROLINAT). Фронт имел выраженный антифранцузский характер. Его лидер Ибрагим Абача объявил на Учредительном Конгрессе: «Мы хотим подлинной независимости Чада и создания правительства, не подчиняющегося Франции. Мы прогрессивная партия, стоящая в оппозицию реакционному правительству» [8]. В программных документах ФРОЛИНА значилось, что главная задача - это свержение диктатуры Ф. Томбалбая, вывод французских военных баз с территории страны, освобождение страны от экономического неоколониализма. Примечательно, что религиозные сюжеты в программе Фронта не затрагивались, никаких сепаратистских положений в ней не было.

Харизматичный лидер, И. Абача смог объединить разрозненные вооруженные группировки, которые вынуждены были эмигрировать с территории Чада в Судан, Египет, и Центральноафриканскую Республику. Вместе со своими соратниками он в 1966 г. вступил на территорию Чад и предпринял попытку поднять массовое восстание против режима Ф. Томбалбая. 11 февраля 1968 г. И. Абача погиб в бою с регулярной армией.
Это была серьезная потеря для чадских северян: после гибели лидера во ФРОЛИНА началась борьба за власть и произошел раскол в рядах Фронта. Номинально генеральным секретарем организации стал Абба Сидик. По его инициативе началась реорганизация ФРОЛИНА, в результате которой Фронт фактически трансформировался в военно-политическую организацию. Вооруженные силы организации были разделены на два крупных соединения. Первая армия контролировала центральные и западные районы и сохраняла верность А. Сидику. К ней примыкали также зарубежные секции ФРОЛИНА в Ливии, Каире и Центральноафриканской республике. Вторая армия контролировала провинции Борку, Эннеди, Тибести и находилась под влиянием Хиссена Хабре и Гукуни Уэддея; к ним примыкали суданская и нигерийская зарубежные секции Фронта.

Несмотря на раскол в рядах ФРОЛИНА и острые противоречия между ее лидерами и идеологами, партизаны сумели достичь существенных успехов в боях с регулярной армией при поддержке Ливии.

Военные действия на севере разворачивались на фоне тяжелого политического и экономического кризиса в стране. Ф. Томбалбай, страдавший манией преследования, повсюду видел заговоры и предательства. Все те, кто осмеливался выразить недовольство режимом, оказывались в тюрьме или, в лучшем случае, высылались из страны. Какая бы то ни было политическая деятельность была под запретом, оппозиция была полностью разгромлена. Удручающее положение в экономике и полная неспособность режима обеспечить рост производства в аграрном секторе вызывало ропот практически во всех слоях чадского общества. Диктатор понял, что режим личной власти может рухнуть в любой момент и в августе 1968 г. обратился за военной помощью к Франции.

Франция ввела войска на территорию Чад в районе Тибести. В состав экспедиционного корпуса входили морская пехота с вертолетами, две роты легионеров и большая группа советников [9]. (По некоторым данным в партизанских отрядах северян присутствовали военные советники из СССР и ГДР.)

\section{Операция «Бизон»}

14 апреля 1969 г. президент де Голль объявил о начале операции «Бизон» (Bison) [10]. В Чад был направлен дополнительный воинский контингент под командованием полковника Ганьо, включавший более 1 тыс. штыков. Регион Борку - Эннеди Тибести стал основным театром военных действий в период с 11 января по 10 марта 1970 г. В результате этой масштабной операции к июню 1971 г. от 
ФРОЛИНА остались лишь разрозненные группы партизан в Тибести. Французские легионеры до начала июля «зачищали» горный массив, иначе говоря, проводили карательные операции. В дальнейшем французские специалисты совместно с офицерами израильских спецслужб занялись обучением чадских военнослужащих и президентской гвардии, сформированной из марокканцев.

Уход французов и плачевное состояние правительственной чадской армии обусловили начало вооруженного пограничного конфликта между Ливией и Республикой Чад. В колониальном прошлом Франция и Италия так и не смогли демаркировать эту границу. Яблоком раздора стала узкая (всего 100 км.) полоса пустынной земли Аузу, населенной последователями суфийского ордена сенусийя (большая часть последователей этой религиозной секты проживает на территории Ливии). Последнее обстоятельство и послужило поводом для начала военной операции ливийской армии, начавшейся в 1972 г. и закончившейся в 1976 г. аннексией этой территории Ливией. Острота противостояния объяснялась тем фактом, что на этой территории были обнаружены залежи урановых руд и нефти [11].

Уход французов лишь усилил страхи Ф. Томбалбая и побудил его усилить репрессии. В 1973 г. он распустил правящую партию «как не справившуюся с задачей национального возрождения» [12]. На смену ей пришло Национальное движение за культурную и социальную революцию - НДКСР (Mouvement national pour la Revolution Culturelle et Sociale - MNRCS). Это политическое шоу должно было по замыслу его инициаторов убедить граждан страны в том, что грядут серьезные перемены, в частности, вектор политического развития должен был заметно сместиться влево. Новая властная политическая структура создавалась на базе распущенной ППЧ и генеральным секретарем ее, разумеется, стал $Ф$. Томбалбай. Членство в партии было объявлено обязательным для всех сознательных пролетариев, которые отныне должны были отчислять в партийную кассу не менее одного процента своей зарплаты. Были упразднены все религиозные организации, распущены все католические миссии. Традиционный культ йондо был объявлен государственной религией. Была проведена массовая компания африканизации всех имен и географических названий. В марте 1974 г. была официально вербализована доктрина «чадского социализма». Чадская «культурная революция» очевидно имела китайский прототип и в этот период Китай поддерживает режим Ф. Томбалбая, в том числе, значительными кредитами. Наряду с Китаем Республика Чад быстро сближалась с Северной Кореей и Румынией [13].

\section{Апрельский путч 1975 года}

Все это никак не могло обрадовать Францию, отношения которой с Республикой Чад быстро ухудшались [14]. Ф. Томбалбай продемонстрировал свою полную неспособность управлять вверенной ему страной и должен был уйти. В ночь на 13 апреля 1975 г. в стране был совершён военный переворот, его инициатором был майор Вадаль Абделькадер Камуге (позже он был назначен Министром иностранных дел), непосредственное руководство путчем принял на себя бригадный генерал Ноэль Одингара (он стал главнокомандующим вооружёнными силами). В ходе штурма президентской резиденции Ф. Томбалбай был тяжело ранен и вскоре скончался. Утром в Нджамену на грузовиках прибыло подкрепление, солдаты палили в воздух и кричали: «Мы победили! Да здравствует Республика!». Гибель президента не вызвала никакого сожаления у жителей столицы, которые после сообщения по радио о смерти Ф. Томбалбая, устроили пляски под песенку «Томбалбай мёртв!» [15]. Сразу после переворота путчисты объявили о своей готовности выполнять все международные обязательства, гарантировало иностранцам их безопасность и защиту их интересов. Что важно, они официально призвали командование французских войск в Чаде не вмешиваться в события (на тот момент в стране находились 2 тыс. французских военных) [16]. Но, судя по всему, французы и не собирались этого делать. Агенты «Франсафрик» не могли не знать о готовящемся перевороте, под их руководством находились тогда национальная гвардия и элитные части правительственных войск, состоящие из кочевников [17]. На следующий день путчисты опубликовали воззвание, в котором, в котором Ф. Томбалбай, впавший в немилость хозяина Елисейского дворца, обвинялся в поощрении сепаратистов, развале государства, разжигании племенной («этнической») вражды и в оскорблении национальной армии.

Власть перешла к Высшему военному совету $(\mathrm{BBC})$, главой которого стал бывший офицер французской армии, ветеран вьетнамской войны, бригадный генерал Феликс Маллум, который с 1973 г. находился в тюрьме по обвинению в заговоре против президента. Все члены ВВС были старшими офицерами, в свое время окончившими французские военные учебные заведения и дослужившимися до звездных погон еще во французской армии. Примечательно, что сразу после путча, BВC обратился с просьбой к президенту Франции о выводе всех французских войск с территории Республики, что и было сделано в конце октября 1975 года. Операция «Бизон» была завершена, в ходе военных действий Франция потеряла 50 своих солдат. После 
этого в Чад осталась так называемая Миссия военно-технической поддержки (La mission d'Assistance Militaire Technique - AMT), включая большинство старших офицеров военно-морских сил, ранее командированных в эту страну [18].

Но Ф. Маллум, провозгласивший следующий 1976 г. годом национального примирения, явно переоценил свои силы. Когда Нджамену посетил премьер-министр Франции Жак Ширак, Ф. Маллум смиренно просил о возобновлении военного сотрудничества. После неудачной попытки покушения [19] на главу ВВС в 1976 г. Республика Чад и Франция заключили новые военные соглашения, а в 1977 г., после попытки государственного переворота в Нджамене, Франция начала поставки военной техники путчистам. Все это уже тогда наводило на мысль о том, что за организацией военного переворота и убийством вышедшего из доверия французских покровителей Ф. Томбалбая стояли агентурные сети «Франсафрик». Дальнейшие события подтвердили правомерность такого предположения.

Несмотря на глубокий кризис в рядах ФРОЛИНА и его распад на 11 мелких противоборствующих военизированных группировк, северянам в 1978 г. удалось нанести ряд поражений правительственным войскам и захватить половину территории Республики. Власть ВВС даже на юге страны была лишь номинальной. К столице приближались войска Г. Уэддея, которым оказывала содействие Ливия. В этой ситуации Ф. Маллум обратился за военной помощью к тем, кто привел его к власти.

Получив просьбу Ф. Маллума о помощи, президент Франции Валери Жискар д’Эстен стал торопиться с ответом и взял паузу: новая военная экспедиция неизбежно испортила бы отношения Франции с Ливией. Однако положение Ф. Маллума было настолько шатким, а желание Елисейского дворца сохранить влияние в Чад настолько сильным, что в феврале 1978 г. было принято решение начать операцию «Тако» (Tacaud).

\section{Оперпация «Тако»}

В Чад были вновь введены французские войска: в состав экспедиционного корпуса вошли 1200 легионеров, морских пехотинцев и 10 штурмовиков «Ягуар» [20]. Французская военная помощь стала решающим фактором побед правительственной армии в крупных сражениях под Ати и Джода. Комбатанты ФРОЛИНА были вынуждены отступить, оставив на полях сражений значительную часть оружия и снаряжения, полученных из Ливии.

Появление на театре военных действий французских военных изменило баланс сил и спровоцировало дальнейший раскол в рядах оппозиции.
Г. Уэддей со своими сторонниками провозгласил курс на свержение «неоколониалистской диктатуры, навязанной нам Францией» [21]. Напротив, Х. Хабре, контролировавший восточные районы страны и давно открыто демонстрировавший свою симпатию к Франции, вступил в переговоры с Ф. Маллумом и сумел убедить последнего распустить ВВС и сформировать коалиционное правительство - Правительство национального единства. При посредничестве Ливии, Судана и Нигера была выработана «Основополагающая хартия» («Charte fondamentale»), которая предусматривала раздел полномочий между представителями повстанцев и правительством. Мусульмане в кабинете доминировали с незначительным перевесом, а в Совете национальной обороны было по 6 представителей каждой стороны. В результате переговоров главой государства остался президент Ф. Маллум, а кабинет возглавил Х. Хабре. Сетям «Франсафрик» удалось, таким образом, ненадолго усилить вооруженные силы Нджамены и удвоить число политиков, лояльных (в той или иной степени) Франции, во властных структурах Чад.

Но шаткий компромисс не позволил преодолеть политический кризис в стране и уже в начале 1979 г. Х. Хабре начал борьбу за президентское кресло, а 12 февраля случился вооруженный конфликт между сторонниками президента и премьерминистра. Комбатанты Х. Хабре подняли мятеж в Нджамене: нейтрализовав армейские подразделения, верные Ф. Маллуму, они устроили погромы и массовые грабежи мирного населения; на востоке страны, в Абече и Билтине, чиновников, лояльных президенту, казнили без суда. Христиане вынуждены были бежать в южные провинции страны. Уже 22 февраля состоялись ответные погромы на юге, в Мунду, Кума, Сарх, Моиссала. Число жертв с той и другой стороны превысило 10 тыс. человек.

В результате вооруженного противостояния и Ф. Маллум, и Х. Хабре вынуждены были подать в отставку [22]. (Ф. Маллум в июне того же года скончался, разумеется, в парижском госпитале). Было создано новое переходное правительство, в котором Х. Хабре получил портфель министра обороны. Но и это правительство оказалось недееспособным, так как южан, которых представлял командующий жандармерией А. Камуге, не устроило засилье северян в новом кабинете. Вновь возникла угроза возобновления полномасштабной войны между Севером и Югом.

В августе 1979 г. по инициативе Организации Африканского Единства в Лагосе состоялась конференция, к участию в которой были приглашены лидеры всех противоборствующих группировок. В итоге было подписано коммюнике, предусматривающее формирование Правительства нацио- 
нального единства (ПНЕ), разоружение комбатантов, среди прочего, вывод французских войск с территории Республики Чад. 12 ноября 1979 г. такое правительство было сформировано; премьерминистром был назначен Г. Уэддей, а министром обороны вновь стал Х. Хабре. 11 портфелей в ПНЕ принадлежали южанам, 13 северянам и три - креатурам стран-посредников. Но предусмотренное взаимными обязательствами разоружение не состоялось. Взаимное недоверие было настолько сильно, что христиане отказывались возвращаться в столицу и северные регионы страны, даже члены правительства посещали Нджамену лишь в день заседания кабинета.

Создание ПНЕ не ознаменовало собой прекращение вооруженного конфликта: камнем преткновения вновь стали неуемные амбиции Х. Хабре. 22 марта 1980 г. возник новый масштабный конфликт между его сторонниками и «правительственной» армией. Как к той, так и к другой противоборствующей стороне примкнули отдельные малочисленные отряды боевиков. Более шестисот заирских и французских миротворцев, присланных в страну по условиям мирного договора, практически не вмешивались в уличные бои в Нджамене, а в апреле-мае и вовсе покинули страну в соответствии с условиями Лагосской конференции. В результате девятимесячной борьбы за контроль над столицей погибли несколько тысяч человек [23]. После того, как стало ясно, что никто из соперников не сможет одержать окончательную победу без поддержки извне, Х. Хабре отвел своих сторонников в Тибести, Г.Уэддей отступил в Ливию, А. Камуга установил контроль над южными районами страны.

В ситуации военно-политического хаоса в Чад Франция предпочла в мае 1980 г. вывести свои войска из зоны конфликта, операция Tacaud завершилась. После очередного ухода французских войск Г.Уэддей предпринял дипломатический демарш: уже в июне он заключил соглашение о дружбе и сотрудничестве с Ливией, а в декабре 1980 г. обратился к Муаммару Каддафи за военной помощью.

\section{Интервенция Ливии в Республику Чад}

В результате ввода ливийских танков и девятитысячного контингента ливийских войск в Чад военные действия в стране временно прекратились. По некоторым данным в операции участвовали военные советники из ГДР и СССР [24]. 15 декабря 80 г. Х. Хабре и его соратники были вынуждены покинуть страну. Воодушевленные успехом Г. Уэддей и М. Каддафи подписали в январе 1981 г. декларацию о намерении объединить Ливию и Республику Чад в единую Джамахирию. Впрочем, лидеры двух стран заявили, что это не более, чем декларация о намерениях и объединение государств возможно только после референдума и проведения демократических выборов в Чад.

Это не могло порадовать Францию, которая не желала портить отношения с М. Каддафи и терять очень выгодные и столь необходимые для нее в то время контракты на поставки ливийской нефти. Это побудило Елисейский дворец к политическому маневру: военная и финансовая помощь теперь была адресована Х. Хабре. Сети «Франсафрик» инспирировали отправку в Чад африканских миротворцев: воевать за интересы Франции должны были миротворцы из Заира, Нигерии и Сенегала.

Американцы, в отличие от французов, меньше опасались конфронтации в отношениях с М. Каддафи. 20 января 1981 г. США разорвали дипломатические отношения с Ливией и объявили лидера Джамахирии спонсором международного терроризма. Рональд Рейган заявил о поддержке Х. Хабре, сконцентрировавшего свои силы в Дарфуре и побуждал его выступить против правительства Республики Чад [25].

Это вновь изменило расстановку сил на чадской политической сцене: фактически Х. Хабре получил карт-бланш на военное противодействие ливийской группировке и резко усилил свои позиции: США начали поставки современного летального оружия лидеру северян. После того, как Франция и США в октябре 1981 г. вынудили М. Каддафи вывести своих солдат с территории Чад, Х. Хабре возобновил военные действия против войск, сохранявших верность ПНЕ. В конце 1981 г. он начал наступление на востоке Чад, 5 июня 1982 г. состоялась битва при Массагет в непосредственной близости от Нджамены. Французские ВBC обеспечивали повстанцам прикрытие с воздуха. 7 июня после тяжелых боев войска северян вошли в Нджамену.

Г. Уэддей с частью его правительства бежал на север страны и вновь запросил помощи у Ливии. Лидер Джамахирии вновь направил своих солдат в Чад. Войска, верные ПНЕ, при поддержке ливийцев (всего около 6 тыс. штыков) начали наступление на группировку Х. Хабре. Но силы оказались примерно равными и окончательной победы не удалось достигнуть ни одной из противоборствующих сторон. В результате на территории Республики Чад были сформированы два правительства: Х. Хабре, объявивший свой кабинет единственно легитимным, обосновался в столице страны Нджамене, а правительство Г. Уэдея расположилось в г. Бардай.

Тем временем возник острый конфликт на юге страны: темнокожие чадцы взбунтовались против диктаторских методов администрирования и коррупцией полковника Камугу. Х. Хабре быстро оценил ситуацию и бросил своих комбатантов на города Сарх и Мунду. 4 сентября 1982 г. он установил 
свой контроль над большей частью территории страны. Приняв президентскую присягу, Х. Хабре сформировал новый кабинет, в который постарался ввести представителей всех оппозиционных сил, и объявил, что намерен проводить политику национального примирения. Под политическим прикрытием США и Франции страна получила место в ООН и поддержку большинства стран ОАЕ.

В октябре 1982 г. в Бардаи собрались те представители оппозиции, которые готовы были поддержать Г. Уэддея в его борьбе с Х. Хабре. За счет ливийцев и при участии ливийских офицеров-инструкторов лидеру южан удалось набрать и обучить около 4 тыс. бойцов. В январе 1983 г. арабский легион и ливийский воинский контингент, подчиненный Г. Уэддею, включал приблизительно 12 тыс. комбатантов. У Х. Хабре было на тот момент около 10 тыс. штыков.

Усиление позиций Ливии в регионе не могла устроить США и Францию. В феврале 1983 г. американский авианосец «Нимитц» продемонстрировал флаг близ территориальных вод Ливии. В августе США организовали военные маневры «Брайт Стар - 83» на территории Судана и Египта. В общей сложности у границ Ливии были сконцентрированы 5,5 тыс. американских солдат и крупная авиационная группировка. М. Каддафи в свою очередь приступил к созданию на территории Дарфура «исламского легиона», основу которого составили комбатанты вооруженных группировок чадских северян и кочевники Сахеля, преимущественно воинственные туарегские племена.

К лету 1983 г. Г. Уэддей, нанеся крупное противнику, завладел 24 июня г. Файо Ларго (атаке наземных войск предшествовали ковровые бомбардировки ливийских ВВС) и взял г. Абеча. В критической ситуации Заир направил 2 тыс. десантников, которые заняли позиции близ Нджамены, высвободив значительные силы, которые Х. Хабре смог перебросить на фронт; США в этой ситуации оказали ему серьезную финансовую помощь. Все это позволило Х. Хабре 30 июля 1983 г. вернуть города Абеча и Файо Ларго. Впрочем, уже 10 августа ливийский экспедиционный корпус (5 тыс. штыков), направленный на помощь Г. Уэддею позволил последнему вернуть Файо Ларго.

Во время боев за Файо-Ларго на помощь Х. Хабре были направлены французские инструкторы, призванные обслуживать переносные ракетные комплексы. Однако просьбы Х. Хабре обеспечить ему поддержку с воздуха остались без ответа.

И все же бывшая метрополия больше не могла оставаться в стороне, ведь под угрозой оказалась вся ее система безопасности в Центральной Африке. Но приказ об интервенции социалист Миттеран отдал с большой неохотой. Решающим моментом стало огромное давление, которое оказали на него американские союзники, но, прежде всего, главы дружественных африканских режимов - Феликс Уфуе-Буани, Омар Бонго, Абду Диуф и Мобу- ту Сесе Секо. Они настаивали, что все те гарантии безопасности африканских стран, которых постоянно заявляет Франция, окажутся весьма сомнительными, если не начнется французская интервенция в Чад.

\section{Операция «Манта»}

Угроза укрепления позиций М. Каддафи в Чаде и перспектива возникновения объединенной Джамахирии, а также нарастающее давление со стороны «заклятых американских союзников» заставили все-таки Францию вновь вмешаться в этот невероятно сложный конфликт. Тем более, что к этому ее настойчиво побуждали самые одиозные африканские диктаторы, сателлиты Франции Феликс Уфуйе-Буани, Омар Бонго и Мобуту Сесе Секо. 10 августа 1983 г. президент Франции Франсуа Миттеран распорядился начать операцию «Манта» («Manta»), в ходе которой в Чад были переброшены 3,5 тыс. легионеров, морских пехотинцев и десантников. Туда была направлена мощная группировка бронетехники, 14 военных самолетов и боевых вертолетов различного типа.

В результате проведения этой операции территория Республики Чад оказалась разделенной на две части по 16 параллели. Эта «красная линия» была хорошо укреплена и охранялась французскими военными. Французы декларировали стремление вернуть противоборствующие стороны за стол переговоров, рассчитывая при этом сохранить свое политическое, экономическое и военное доминирование на всей территории Республики.

Противостояние продолжалось до середины 1984 г., в течении этих месяцев влияние Г. Уэдея падало, а число сторонников быстро сокращалось. ПНЕ распался, часть министров и ряд влиятельных политиков создали в Париже Комитет координации и действий. В заявлении лидеров этой политической структуры глава ПНЕ был объявлен несостоятельным лидером. Парижские диссиденты объявили войну как Г. Уэддею, так и Х. Хабре. Первый оказался, таким образом, в политической изоляции. Франция вновь сделала ставку на второго. Это стало поводом для переговоров между Францией и Ливией, в ходе которых было принято решение об одновременном выводе французских и ливийских войск с территории Республики Чад [26]. Выводя свои войска с территории Чада, Франция организовала там Миссию военной помощи, задачей которой стала реорганизация и обучение национальной армии. 
Примечательно, что ливийцы также не намеревались строго следовать букве и духу мирных договоренностей. В военных лагерях, расположенных близ Тибести, Фада и Файя Ларго у Г. Уэддея оставались около 5 тыс. собственных солдат и приблизительно столько же ливийцев. Более того, в Файя Ларго ливийские военные специалисты начали строительство военного аэродрома.

В это время Х.Хабре укреплял свои политические позиции: он отказался от бренда «ФРОЛИНА» и создал новую политическую структуру - Национальный союз за революцию и независимость - НСРH (L'Union nationale pour la révolution et l'indépendance - UNRI). Формируя Исполнительный комитет вновь созданной партии, Х. Хабре, следуя своей тактике соединять несоединимое во властных структурах, распределил портфели между южанами и северянами практически поровну. Это на некоторое время смягчило напряженность, но вскоре возникла новая проблема: 4 южные префектуры восстали против Нджамены, практически на всей территории юга страны власть перешла к группировке «Кодос».

Правительственные войска, направленные на подавление мятежа, действовали жестоко, причем страдали в основном мирные жители, в сопредельные страны устремился поток беженцев (по некоторым данным их число достигло 25 тыс. чел. [27]). Это происходило на фоне страшной засухи и голода и вошло в историю Республики Чад как «черный сентябрь». К концу 1984 г. «некоторые южные суб-префектуры, по свидетельству членов миссии ЮНИСЕФ, превратились в зону бедствия» [28]. Партизан из группировки «Кодос» удалось нейтрализовать лишь к началу 1985 года. Сделать это удалось как силой оружия, так и силой убеждения, подкрепленной французскими деньгами. 1200 комбатантов согласились выступить в ряды правительственных войск за солидное вознаграждение.

\section{Операция «Ястреб»}

Несмотря на некоторую стабилизацию ситуации в стране, незначительные боестолкновения вдоль «красной линии» продолжались два года. Г. Уэддей готовился к новой войне и наращивал боеспособность своей армии при поддержке Ливии. Наконец 10 февраля 1986 г. его комбатанты совместно с ливийскими регулярными войсками перешли условный рубеж 16-й параллели и двинулись на Нджамену. Агенты «Франсафрик» инспирировали обращение X. Хабре к французскому правительству с просьбой о поддержке действий национальной армии Республики Чад. Чадский президент просил Елисейский дворец о нейтрализации ливийской военной авиабазы в Файя Ларго с целью исключить поддержку армии сепаратистов с воздуха.

Париж на этот раз отреагировал быстро: 13 февраля 1986 г. началась еще одна операция французских войск в Африке - операция «Ястреб» («Epervier»). В отличие от операции «Манта», эта операция предполагала только воздушные удары [29]. В Чад были направлены около 4 тыс. штыков для защиты авиационной базы, а также воздушный полк, имевший на вооружении восемь штурмовиков «ягуар» и четыре многоцелевых истребителя «мираж». (В марте американцы направили для поддержки союзников батарею ЗРК средней дальности.) В пригородах Нджамены был сооружен мощный радар, который впоследствии успешно использовался во время боестолкновений с ливийскими истребителями. (В марте 1986 г. Франция направила в Чад еще полк морской пехоты и две роты десантников: к этому времени французский экспедиционный корпус в Чаде насчитывал более 900 чел.)

16 февраля французская авиация практически полностью разрушила авиабазу в Уади-Дум, которая позволяла ливийским штурмовикам атаковать Нджамену. В ответ на это ливийский дальний бомбардировщик российского производства (Ту-22Б) нанес удар по аэропорту Нджамены. (На обратном пути он был сбит ракетой французской ПВО).

Авиационное прикрытие наземной операции позволило Х. Хабре в декабре 1986 г. сконцентрировать силы и начать наступление на север. К этому времени армия северян почти полностью состояла из ливийцев, которые понесли большие потери после нескольких стычек с правительственными войсками. Но к марту 1987 г. М. Каддафи довел численность своей военной группировки в Чаде до 11 тыс. чел. и отдал приказ начать контрнаступление на Нджамену.

В это время произошло нечто неожиданное: ПНЕ распалась, комбатанты Г. Уэддея из Народных вооруженных сил (НВС, вооруженный отряд ПНЕ) вступили в вооруженный конфликт с отрядом полевого командира Шейха ибн Умара, который фактически представлял интересы М. Каддафи. После того, как сторонники Г. Уэддея потерпели поражение, в северных провинциях начались гонения на неарабское население. Это привело к росту числа сторонников НВС, в особенности после того, как ливийцы арестовали самого Г. Уэддея.

В конфликт поспешили вмешаться агенты сетей «Франсафрик». В ночь с 16 на 17 сентября 1987 г. транспортные самолеты сбросили на парашютах комбатантам НBC все необходимое для ведения автономных боевых действий, включая самое современное ракетное оружие. Но выяснилось, что комбатанты не обладают достаточным уровнем 
технической подготовки, чтобы успешно применять это оружие в бою. Это побудило агентов DGSE десантировать в провинцию Тибести 60 военных инструкторов, которые занялись подготовкой партизан и сборкой оружия.

В декабре 1986 г. ливийские войска начали наступление в провинции Тибести. Однако столкнулись здесь с серьезным сопротивлением реформированной чадской армии. Французские специалисты реформировали национальную армию и изменили тактику ведения боевых операций. Теперь правительственные войска наносили стремительные фланговые удары, используя пикапы с установленными в кузове крупнокалиберными пулеметами. Численность национальной армии была увеличена почти в три раза и достигла 30 тыс. чел.

\section{Война «Тойот»}

В январе 1987 г. начался новый этап вооруженного противостояния, который позже назвали «война тойот». Боевые действия велись с переменным успехом, на стороне армии Х. Хабре выступали войска французского экспедиционного корпуса. К осени стало очевидным, что успех не на стороне Ливии: правительственные войска Чада вступили в аннексированный Ливией приграничный оазис Аузу и, используя этот плацдарм, совершили рейд на ливийскую территорию в район Маатан ас Сарра. Елисейский дворец, опасаясь возможной интервенции Республики Чад против Ливии, начал побуждать Х. Хабре к перемирию. 11 сентября 1987 г. последний подписал с М. Каддафи соглашение о прекращении огня. «Война тойот» на этом завершилась. Ливия вынуждена была уйти с территории Аузу. (Позже, после нескольких раундов трудных переговоров, в 1994 г. Международный суд $00 \mathrm{H}$ вынес решение о суверенитете Чада над этой территорией.)

В октябре 1988 г. были восстановлены дипломатические отношения между Ливией и Республикой Чад. Только после этого Франция сократила численность своего воинского контингента в Чад до 1 тыс. чел.

\section{Путч Идриса Деби}

Несмотря на победу Х.Хабре, ситуация в стране оставалась сложной. 1 апреля 1989 г. советник президента Х. Хабре по безопасности Идрис Деби и несколько других высокопоставленных чиновников из силовых ведомств предприняли попытку вооруженного переворота. (И. Деби фигура примечательная. В 70-е гг. он обучался во Франции и получил диплом военного летчика. В 1978 г. вернулся в Чад и встал под знамена Х. Ха- бре. В 1982 г. принимал участие в свержении президента Г. Уэддея.) Апрельский заговор против Х.Хабре был раскрыт, почти все его участники были убиты. Только И. Деби удалось бежать сперва в Ливию, а затем в Дарфур [30]. При поддержке М. Каддафи он создал достаточно мощную вооруженную группировку и со своей базы в Судане начал совершать регулярные нападения на войска, верные правительству Чада.

Франция на сей раз не пожелала встать на защиту своего бывшего фаворита: Х. Хабре к этому времени все более явно демонстрировал свои симпатии к Белому дому, а Елисейский дворец не хотел допустить усиления позиций своего «заклятого союзника» в регионе. К тому же «холодная война» закончилась, а с ней и борьба за континент между Западом и Востоком. Есть основания думать, что заговор против опального президента был инспирирован агентами «Франсафрик». Известно, что во время марша И. Дэби на Нджамену его сопровождал офицер DGSE Поль Фонбонн. Когда повстанцы занимали столицу, французы оставались нейтральными, охраняли аэропорт, посольство и электростанцию и обеспечивали эвакуацию европейцев [31].

30 ноября 1990 г. после того, как повстанцам удалось захватить г. Абеше, Х. Хабре бежал из своей резиденции в Камерун, а комбатанты под командованием И. Деби вступили в Нджамену. Президент Х. Хабре был отстранен от власти, а новым президентом 2 декабря 1990 г. был провозглашен И. Деби. В июле 1996 г. И. Деби подтвердил свою легитимность, набрав $71 \%$ голосов избирателей на президентских выборах. Позже он одержал победу на майских выборах 2006 г. и на апрельских выборах 2011 г.

Новый президент республики Чад пользуется покровительством Франции и поныне. Известно, Французская авиация в 1992 году активно помогала правительственным частям в подавлении двух военных мятежей, инспирированных Х. Хабре. Операция французских ВВС «Ястреб» продолжалась до 2002 г. по просьбе президента И. Деби. В стране также была размещена группировка французских сухопутных сил.

\section{Вторая гражданская война в Чаде}

Кровавый конфликт в Дарфуре имел как следствие возобновление широкомасштабных боевых действий на территории Республики Чад. Поводом для начала военных действий послужила официальная поддержка суданским правительством чадских сепаратистов, атаковавших в декабре 2005 г. город Адре. В ответ на этот политический демарш Судана И. Деби в своем обращении к нации объявил о на- 
чале войны с этой недружественной Чаду страной. С этого времени Чад оказывал помощь сепаратистам суданского Дарфура.

Пользуясь военной и политической поддержкой Судана, комбатанты из оппозиционного И. Деби Объединенного фронта за перемены весной 2006 г. двинулись на Нджамену и 13 апреля захватить здание Национальной ассамблеи. Однако вскоре верные И. Деби войска выбили комбатантов из столицы. В результате 370 чел. были убиты и 270 попали в плен. Эти события побудили Париж в апреле 2006 г. нарастить свое военное присутствие в Чаде до 1,5 тыс. чел. Позже, в декабре 2007 г. этот контингент был включена в европейскую миротворческую миссию в Чаде и ЦАР под мандатом ОOH [32].

В ответ на поддержку чадских сепаратистов Суданом, власти Чада направили в Дарфур правительственные войска для поддержки повстанцев и предоставили территорию своей страны для прохода на территорию Судана всем вооруженным группировкам, которые пожелали противостоять официальному Хартуму.

В 2007 г. лидер Джамахирии инициировал мирные переговоры в Триполи между правительством Республики Чад и представителями основных группировками повстанцев. 25 октября 2007 г. в Сирте было подписано мирное соглашение; на подписании договора присутствовали И. Деби, Омар аль-Башир и М. Каддафи. Повстанцы и правительство договорились о прекращении огня, проведении всеобщей амнистии и инкорпорации повстанцев в состав вооруженных сил [33].

Но уже в ноябре того же года в стране вновь начались боевые действия. Посольства Франции и США в Чаде объявили о подготовке к эвакуации своих граждан из страны. В стране было введено чрезвычайное положение, были закрыты школы, суды, приостановлено действие Конституции. 28 января 2008 г. более 300 пикапов с крупнокалиберными пулеметами и противотанковыми ракетами с территории Судана двинулись на Нджамену. 1 февраля правительственные войска остановили их на подступах к столице, но повстанцы прорвали оборону верных И. Деби подразделений. 2 февраля две тысячи боевиков блокировали президентский дворец в столице. Французы предложили И. Дэби эвакуацию его и членов его семьи, но тот ответил отказом.

Спасти правительственные войска от разгрома вновь позволило вмешательство французских войск. Благодаря французской авиации была остановлена группа боевиков на 300 автомобилях, пытавшаяся прорваться из Дарфура на помощь основным силам, сражавшимся в Нджамене. Более тысячи легионеров защищали столичный аэропорт, обеспечивая эвакуацию иностранных граждан. Несмотря на заявления министра иностранных дел Франции Бернара Кушнера о том, что Франция не принимала участия в боевых действиях, французские СМИ распространили информацию о том, что французский спецназ участвовал в уличных боях [34].

6 февраля И. Деби встретился с министром обороны Франции Эрве Мореном и, вероятно, получил заверения в дальнейшей поддержке. После этого президент Чада на пресс-конференции объявил о разгроме противника, обвинив Судан в помощи сепаратистам [35].

Год спустя, в январе 2009 г. восемь повстанческих группировок северян объединились в «Союз сил сопротивления» для свержения И. Деби и в стране вновь начались военные действия. Франция вновь защитила свою креатуру. На тот момент французский контингент численностью в 800 чел. входил в состав сил Миссии ООН в Чаде и Центральноафриканской республике. Кроме того, 1150 французских военнослужащих были дислоцированы на французской военной базе в Чаде в рамках операции «Ястреб». Статус французских военных подразумевал оказание тыловой и санитарной поддержки чадским вооруженным силам, в том числе и предоставление данных воздушной разведки [36].

Столкновения продолжались год и не привели к серьезным изменениям военно-политической ситуации в стране. Для всех участников этого конфликта стало понятно, что чадская проблема не имеет военного решения. В январе 2010 г. был подписан новый мирный договор между Суданом и Республикой Чад, который позволил открыть границу между странами и вывести подразделения чадских вооруженных сил из Судана. Однако и это событие не ознаменовало собой нормализацию ситуации в Чаде. После того, как ООН приступила к выводу миротворческих сил с территории страны, в Чад начались репрессии и этнические чистки.

\section{Резюме}

Гражданская война в Республике Чад - это один из самых драматичных эпизодов постколониальной истории Черного континента. Слишком важное стратегическое положение занимает эта страна, слишком важен был для энергетической самодостаточности Франции найденный на ее территории уран, слишком велико желание бывшей метрополии сохранить в ней свои экономические и политические позиции, слишком много новых акторов проявило интерес к этой истерзанной войной стране. Столкновение и причудливое пере- 
плетение интересов различных государств, их разнонаправленная политика по отношению к противоборствующим в Чаде силам сделала конфликт таким фатально продолжительным.

Елисейский дворец не мог допустить стабилизации политической и экономической ситуации в Республике: независимая и национально-ориентированная внешнеэкономическая политика страны неизбежно подорвала бы эксклюзивные позиции французского капитала в чадской экономике и, что особенно важно, угрожало бы ее энергетической безопасности. Именно поэтому сети агентурные сети «Франсафрик» постоянно репродуцировали конфликтные ситуации и делали противостояние практически перманентным. Как констатировал самый известный специалист по деятельности французских спецслужб Феликс-Ксавье Вершав «в Чаде французские сети вооружали и финансировали оба враждующих лагеря, что позволяло ослабить государство и обескровить страну, чтобы легче навязать выгодные для себя концессии» [37].

Искусственно создавалась такая ситуация, при которой властным элитам и лидерам сепара- тистов было выгодно воевать. В одном аналитическом обзоре очень точно сказано «любому, кто объявлял себя повстанцем, были практически гарантированы ливийские деньги и поддержка, а деньги от США и Франции фактически делали войну главной чадской индустрией, тогда как малое количество участников позволяло им на эти деньги хорошо жить» [38]. Неоднократно было отмечено, что французы, опираясь на свои военные базы в Чаде, держат под ударом всю центральную, западную, северную и восточную Африку и одновременно контролируют урановые месторождения [39]. Именно с военной базы, расположенной близ Нджамены, перебрасывались войска в Мали, когда там возникла угроза перехода урановых рудников под контроль мятежных туарегов. Как справедливо отметил С. Балмасов, именно этим объясняется то, что Франция «так цепляется за чадские пески и ведет там почти 40-летнюю войну» [40]. В контексте грядущей реколонизации Черного континента можно предположить, что Чад в обозримом будущем ждут новые потрясения.

\section{Библиография:}

1. Политические партии современной Африки. М., 1984. С. 204.

2. Франсуа Томбалбай (Люди и события) // Новое время. М., 1969. № 33. С. 32.

3. Сагаян Л.Ю. Республика Чад. Справочник. М., 1993. С. 47.

4. Lisette Y., Dumas M. Le RDA et le Tchad - Histoire d'une décolonisation. Présence africaine, 1986.

5. Политические партии зарубежных стран. Справочник. М., 1967. С.236

6. Conflictologist / Chade - http://www.conflictologist.org/main/grajdanskaya-vojna-v-chade.htm

7. Коновалов И.П. Военные операции Франции в Африке - http://coollib.com/b/303689

8. Сагаян Л.Ю. Республика Чад. Справочник. М., 1993. С. 51.

9. Les Opérations Extérieures: Tchad - http://www.fncv.com/biblio/conflits/autres/pays/tchad/index.html

10. Opération Bison - http://www.troupesdemarine.org/actuel/operations/tchad.htm

11. Libya Issue Brief // Congressional Research Service (US State Department) - http://fpc.state.gov/documents/ organization/9577.pdf

12. Сагаян Л.Ю. Республика Чад. Справочник. М., 1993. С. 52.

13. Ежегодник БСЭ. 1975. М., 1975. С. 429

14. Troupes de marine: Tchad 1968-2002 - http://www.troupesdemarine.org/actuel/operations/tchad.htm

15. Meredith M. The State of Africa. L., Free Press. 2005. C. 352-355.

16. CHAD: Death of a Dictator - http://content.time.com/time/magazine/article/0,9171,917376,00.html

17. Коновалов И.П. Военные операции Франции в Африке - http://coollib.com/b/303689

18. Troupes de marine: Tchad 1968-2002 - http://www.troupesdemarine.org/actuel/operations/tchad.htm

19. Лашкул В. Покушение на президента Чада // Известия. 1976. 15 апреля.

20. Opération Tacaud (février 1978-mai 1980) - http://www.troupesdemarine.org/actuel/operations/tchad.htm

21. Conflictologist / Chade - http://www.conflictologist.org/main/grajdanskaya-vojna-v-chade.htm

22. Décès de l'ex-président Félix Malloum - http://www.jeuneafrique.com/159820/politique/d-c-s-de-l-ex-pr-sident-f-lixmalloum/

23. Conflictologist / Chade - http://www.conflictologist.org/main/grajdanskaya-vojna-v-chade.htm

24. Conflictologist / Chade - http://www.conflictologist.org/main/grajdanskaya-vojna-v-chade.htm

25. Костелянец С.В. Конфликт в суданском регионе Дарфур: региональный аспект // Восток. 2015. № 1. С. 3.

26. Opération Manta - http://www.troupesdemarine.org/actuel/operations/tchad.htm

27. Conflictologist / Chade - http://www.conflictologist.org/main/grajdanskaya-vojna-v-chade.htm

28. Buijtenhuijs R. Le FROLINAT et les guerre civiles du Chad (1974-1984). La revolution introuvable. Paris, Editions KARTHALA. 1987. P. 423.

29. Opération Epervier (14 février 1986-2 décembre 2002) - http://www.troupesdemarine.org/actuel/operations/tchad.htm

30. Kenna Mc. A. Idriss Déby: President of Chad - http://www.britannica.com/biography/Idriss-Deby

31. Коновалов И.П. Военные операции Франции в Африке - http://coollib.com/b/303689

32. Waal A. Chad: Civil war, power struggle and imperialist interference - http:////www.greenleft.org.au/node/39011

33. Sudan issue brief no. 9: Echo effects-Chadian instability and the Darfur conflict - http://reliefweb.int/report/sudandarfur-conflict 
34. Коновалов И.П. Военные операции Франции в Африке - http://coollib.com/b/303689

35. Chadian President Idriss Deby gives a press conference Wednesday after a meeting with French Defense Minister Herve Morin - http://www.nbcnews.com/id/23031600/\#.ViDz0tIcTcs

36. Французские источники: армия Чада побеждает повстанцев http://news.mail.ru/politics/2575332/

37. Verschave F.X. La Françafrique. Retranscription de conférences-débat données par F. X. Verschave, président de Survie de 1995 à 2005 - http://survie.org/francafrique/article/la-francafrique.

38. Conflictologist / Chade - http://www.conflictologist.org/main/grajdanskaya-vojna-v-chade.htm

39. Трухачев В. Наёмники-кровавое орудие Запада в Африке - http://www.pravda.ru/world/restofworld/africa/05-022008/254452-naemnik-0/\#

40. Балмасов С. Французская тень над Черным континентом - http://www.pravda.ru/world/restofworld/africa/03-052010/1027946-legion-0/

41. Манойло А.В. Мирное разрешение международных конфликтов: национальные концепции, модели, технологии. // Власть. 2008. № 8. С. 79-83.

42. Манойло А.В. Актуальные вопросы модернизации современной культурно-цивилизационной теории управления международными конфликтами. // Национальная безопасность / nota bene.-2011.-№ 4.-C. 60-66.

43. Вепринцев В.Б. Влияние информационной составляющей на взаимодействие геополитических субъектов // Мировая политика. - 2015. - 1. - C. 192 - 212. DOI: 10.7256/2409-8671.2015.1.12621. URL: http://www.e-notabene.ru/ wi/article_12621.html

44. Виноградова Е.А. Информационные войны в Латинской Америке // Тренды и управление. - 2014. - 4. - С. 372 384. DOI: $10.7256 / 2307-9118.2014 .4 .13080$

45. Карпович О.Г. Международные организации и их роль в предупреждении, урегулировании и разрешении этнополитических конфликтов // Национальная безопасность / nota bene. - 2014. - 3. - C. 398 - 405. DOI: 10.7256/20738560.2014.3.11786.

46. Галвес Деролле П. Brazil - New Age // Конфликтология / nota bene. - 2014. - 1. - C. 136 - 139. DOI: 10.7256/.2014.1.13181.

47. Манойло А.В. Геополитическая картина современного мира и управляемый хаос // Мировая политика. - 2015. 1. - C. 66 - 80. DOI: 10.7256/2409-8671.2015.1.12665. URL: http://www.e-notabene.ru/wi/article_12665.html

48. Карякин В.В. Проблемы российской политологии и пути их решения // Конфликтология / nota bene. - 2015. 3. - C. 243 - 248. DOI: 10.7256/2409-8965.2015.3.16125.

49. Карпович О.Г. Глобальные проблемы международных отношений в контексте формирующегося многополярного мира // Право и политика. - 2014. - 5. - C. 620 - 629. DOI: 10.7256/1811-9018.2014.5.11787.

50. Будаев А.В. Основные подходы к использованию «мягкой силы» в интересах реализации внешней политики Российской Федерации // Тренды и управление. - 2014. - 2. - C. 175 - 187. DOI: 10.7256/2307-9118.2014.2.11784.

51. Ватель А.Ю. Стандарты служебного и этического поведения как метод противодействия коррупции в системе государственной службы // Полицейская деятельность. - 2011. - 6. - С. 10 - 14.

\section{References (transliterated):}

1. Politicheskie partii sovremennoi Afriki. M., 1984. S. 204.

2. Fransua Tombalbai (Lyudi i sobytiya) // Novoe vremya. M., 1969. № 33. S. 32.

3. Sagayan L.Yu. Respublika Chad. Spravochnik. M., 1993. S. 47.

4. Lisette Y., Dumas M. Le RDA et le Tchad - Histoire d'une décolonisation. Présence africaine, 1986.

5. Politicheskie partii zarubezhnykh stran. Spravochnik. M., 1967. S.236

6. Conflictologist / Shade - http://www.conflictologist.org/main/grajdanskaya-vojna-v-chade.htm

7. Konovalov I.P. Voennye operatsii Frantsii v Afrike - http://coollib.com/b/303689

8. Sagayan L.Yu. Respublika Chad. Spravochnik. M., 1993. S. 51.

9. Les Opérations Extérieures: Tchad - http://www.fncv.com/biblio/conflits/autres/pays/tchad/index.html

10. Opération Bison - http://www.troupesdemarine.org/actuel/operations/tchad.htm

11. Libya Issue Brief // Congressional Research Service (US State Department) - http://fpc.state.gov/documents/ organization/9577.pdf

12. Sagayan L.Yu. Respublika Chad. Spravochnik. M., 1993. S. 52.

13. Ezhegodnik BSE. 1975. M., 1975. S. 429

14. Troupes de marine: Tchad 1968-2002 - http://www.troupesdemarine.org/actuel/operations/tchad.htm

15. Meredith M. The State of Africa. L., Free Press. 2005. S. 352-355.

16. CHAD: Death of a Dictator - http://content.time.com/time/magazine/article/0,9171,917376,00.html

17. Konovalov I.P. Voennye operatsii Frantsii v Afrike - http://coollib.com/b/303689

18. Troupes de marine: Tchad 1968-2002 - http://www.troupesdemarine.org/actuel/operations/tchad.htm

19. Lashkul V. Pokushenie na prezidenta Chada // Izvestiya. 1976. 15 aprelya.

20. Opération Tacaud (février 1978-mai 1980) - http://www.troupesdemarine.org/actuel/operations/tchad.htm

21. Conflictologist / Shade - http://www.conflictologist.org/main/grajdanskaya-vojna-v-chade.htm

22. Décès de l'ex-président Félix Malloum - http://www.jeuneafrique.com/159820/politique/d-c-s-de-l-ex-pr-sident-f-lix-malloum/

23. Conflictologist / Shade - http://www.conflictologist.org/main/grajdanskaya-vojna-v-chade.htm

24. Conflictologist / Shade - http://www.conflictologist.org/main/grajdanskaya-vojna-v-chade.htm

25. Kostelyanets S.V. Konflikt v sudanskom regione Darfur: regional'nyi aspekt // Vostok. 2015. № 1. S. 3.

26. Opération Manta - http://www.troupesdemarine.org/actuel/operations/tchad.htm

27. Conflictologist / Shade - http://www.conflictologist.org/main/grajdanskaya-vojna-v-chade.htm

28. Buijtenhuijs R. Le FROLINAT et les guerre civiles du Chad (1974-1984). La revolution introuvable. Paris, Editions KARTHALA. 1987. R. 423. 
29. Opération Epervier (14 février 1986-2 décembre 2002) - http://www.troupesdemarine.org/actuel/operations/tchad.htm

30. Kenna Mc. A. Idriss Déby: President of Chad - http://www.britannica.com/biography/Idriss-Deby

31. Konovalov I.P. Voennye operatsii Frantsii v Afrike - http://coollib.com/b/303689

32. Waal A. Chad: Civil war, power struggle and imperialist interference - http:////www.greenleft.org.au/node/39011

33. Sudan issue brief no. 9: Echo effects-Chadian instability and the Darfur conflict - http://reliefweb.int/report/sudandarfur-conflict

34. Konovalov I.P. Voennye operatsii Frantsii v Afrike - http://coollib.com/b/303689

35. Chadian President Idriss Deby gives a press conference Wednesday after a meeting with French Defense Minister Herve Morin - http://www.nbcnews.com/id/23031600/\#.ViDz0tIcTcs

36. Frantsuzskie istochniki: armiya Chada pobezhdaet povstantsev http://news.mail.ru/politics/2575332/

37. Verschave F.X. La Françafrique. Retranscription de conférences-débat données par F. X. Verschave, président de Survie de 1995 à 2005 - http://survie.org/francafrique/article/la-francafrique.

38. Conflictologist / Shade - http://www.conflictologist.org/main/grajdanskaya-vojna-v-chade.htm

39. Trukhachev V. Naemniki-krovavoe orudie Zapada v Afrike - http://www.pravda.ru/world/restofworld/africa/05-022008/254452-naemnik-0/\#

40. Balmasov S. Frantsuzskaya ten' nad Chernym kontinentom - http://www.pravda.ru/world/restofworld/africa/03-052010/1027946-legion-0/

41. Manoilo A.V. Mirnoe razreshenie mezhdunarodnykh konfliktov: natsional'nye kontseptsii, modeli, tekhnologii. // Vlast'. 2008. № 8. S. 79-83.

42. Manoilo A.V. Aktual'nye voprosy modernizatsii sovremennoi kul'turno-tsivilizatsionnoi teorii upravleniya mezhdunarodnymi konfliktami. // Natsional'naya bezopasnost' / nota bene.-2011.-№ 4.-S. 60-66.

43. Veprintsev V.B. Vliyanie informatsionnoi sostavlyayushchei na vzaimodeistvie geopoliticheskikh sub"ektov // Mirovaya politika. - 2015. - 1. - S. 192 - 212. DOI: 10.7256/2409-8671.2015.1.12621. URL: http://www.e-notabene.ru/wi/ article_12621.html

44. Vinogradova E.A. Informatsionnye voiny v Latinskoi Amerike // Trendy i upravlenie. - 2014. - 4. - S. 372 - 384. DOI: 10.7256/2307-9118.2014.4.13080.

45. Karpovich O.G. Mezhdunarodnye organizatsii i ikh rol' v preduprezhdenii, uregulirovanii i razreshenii etnopoliticheskikh konfliktov // Natsional'naya bezopasnost' / nota bene. - 2014. - 3. - S. 398 - 405. DOI: 10.7256/2073-8560.2014.3.11786.

46. Galves Derolle P. Brazil - New Age // Konfliktologiya / nota bene. - 2014 - 1. - S. 136 - 139. DOI: 10.7256/.2014.1.13181.

47. Manoilo A.V. Geopoliticheskaya kartina sovremennogo mira i upravlyaemyi khaos // Mirovaya politika. - 2015. - 1. S. 66 - 80. DOI: 10.7256/2409-8671.2015.1.12665. URL: http://www.e-notabene.ru/wi/article_12665.html

48. Karyakin V.V. Problemy rossiiskoi politologii i puti ikh resheniya // Konfliktologiya / nota bene. - 2015. - 3. - S. 243 - 248. DOI: 10.7256/2409-8965.2015.3.16125.

49. Karpovich O.G. Global'nye problemy mezhdunarodnykh otnoshenii v kontekste formiruyushchegosya mnogopolyarnogo mira // Pravo i politika. - 2014. - 5. - S. 620 - 629. DOI: 10.7256/1811-9018.2014.5.11787.

50. Budaev A.V. Osnovnye podkhody k ispol'zovaniyu «myagkoi sily» v interesakh realizatsii vneshnei politiki Rossiiskoi Federatsii // Trendy i upravlenie. - 2014. - 2. - S. 175 - 187. DOI: 10.7256/2307-9118.2014.2.11784.

51. Vatel' A.Yu. Standarty sluzhebnogo i eticheskogo povedeniya kak metod protivodeistviya korruptsii v sisteme gosudarstvennoi sluzhby // Politseiskaya deyatel'nost'. - 2011. - 6. - S. 10 - 14. 